FACTA UNIVERSITATIS

Series: Law and Politics Vol. 15, $\mathrm{N}^{\mathrm{o}}$ 1, 2017, pp. 1 - 11

DOI: $10.22190 /$ FULP1701001C

Original Scientific Article

\title{
CRITICAL REVIEW OF THE SECURITY MEASURE OF RESTRAINT TO APPROACH AND COMMUNICATE WITH THE INJURED PARTY UNDER ARTICLE 89a OF THE SERBIAN CRIMINAL CODE
}

\author{
UDC 343.263
}

\author{
Emir Ćorović ${ }^{1}$, Aladin Šemović ${ }^{2}$ \\ ${ }^{1}$ State University of Novi Pazar, Department for Legal Sciences, Republic of Serbia \\ ${ }^{2}$ Higher Court in Novi Pazar, Republic of Serbia
}

\begin{abstract}
In this paper, the authors analyze the security measure involving the restraint to approach and communicate with the injured party under Article 89a of the Criminal Code of Serbia, which was introduced by legislative changes and amendments in 2009. Although this criminal sanction has been part of the domestic criminal legislation for seven years, there are serious legislative deficiencies associated with its regulation. Namely, the positive criminal law of the Republic of Serbia does not regulate the consequences of the act if the convicted offender violates this restraint, nor does it envisage the rules for the execution of this security measure. This can cause serious problems in imposing and applying the relevant criminal sanction. The corresponding data show that courts use this measure to a much lesser extent every year. Thus, the authors give suggestions de lege ferenda to remove the existing restraining order from the system of security measures and to envisage it as one of the obligations under a suspended sentence with supervision.
\end{abstract}

Key words: restraint to approach and communicate with the injured party, security measure, suspended sentence with supervision.

\section{INTRODUCTION}

The security measure of restraint to approach and communicate with the injured party (victim) was first introduces into the Serbian criminal legislation by the 2009 changes and amendments to the Criminal Code of Serbia (CC). ${ }^{1}$ Notably, the rationale of introducing

Received November 28 $8^{\text {th }}, 2016 /$ Accepted March $3^{\text {rd }}, 2017$

Corresponding author: Emir Ćorović, LL.D.

State University of Novi Pazar, Vuka Karadžića bb, 36300 Novi Pazar, Republic of Serbia

E-mail: ecorovic@np.ac.rs

${ }^{1}$ Since its introduction in 2009 until the 2012 amendments to the CC, the name of this security measure was "the measure of restraint to approach and communicate with the injured party". It was the only security measure that was explicitly contained the term "measure", which is considered superfluous in legal theory (Stojanović, 2012: 
this measure was the suppression of the crime of domestic violence, but it is not strictly related to this criminal offence (Ćorović, Milić, 2016), which means that it may be imposed against offenders of other crimes, as indicated in the corresponding data presented further on in this paper. Yet, the introduction of this measure in the CC of Serbia is above all justified by the substantive similarities of this security measure with restraint as a form of civil law protection against domestic violence provided under Article 198 paragraph 2 of the Family Act, which was first introduced in the Serbian legislation through the adoption of the 2005 Family Act (FA). Moreover, the Serbian Misdemeanours Act provides a protective measure prohibiting access to the injured party, premises or place of the offense, which is also similar in content to the security measure of the restraint to approach and communicate with the injured party envisaged in the $\mathrm{CC}$ and the restraining order envisaged in the FA (Vuković, 2015: 121-122).

Since its introduction into the positive law, this criminal sanction has been subject to ample criticism. In this paper, we will refer to the critical remarks not only as a reminder of the legislator's sluggishness in changing the identified deficiencies but also because we consider it very important to identify the practical problems that may be encountered in its implementation. In this regard, we give some suggestions de lege ferenda.

\section{THE RESTRAINT TO APPROACH AND COMMUNICATE WITH THE INJURED PARTY}

According to Article 89a paragraph 1 of the CC, this security measure comprises a prohibition or restraint on: a) approaching the injured party at a specified distance; b) access to an area around the place of residence or workplace of the injured party; c) further harassment of the injured party; d) further communication with the injured party. The court may impose any of these restraints if it is deemed reasonable that the further commission of such actions (approaching, access, harassment and communication) may be dangerous for the injured party.

By envisaging the criterion "danger to the injured party", the legislator endeavoured to determine the legal grounds for imposing this security measure, particularly bearing in mind that Article 78 of the $\mathrm{CC}$ stipulates that security measures are envisaged as a special type of criminal sanctions in Serbian legislation. Namely, Article $78 \mathrm{CC}$ stipulates that the purpose of security measures is to eliminate the circumstances or conditions that may influence an offender to refrain from committing crimes. In this context, the term "circumstances" signifies "the mental state of the offender" (Stojanović, 2012: 78), while the term "conditions" implies "certain situations that encourage the commission of a criminal act and may contribute to recidivism" (Srzentić et all., 1979: 475). Thus, the term "circumstances" refers to the sources of danger (stemming from to the offender) which call for the application of the so-called medical security measures, whereas the term "conditions" refers to the sources of danger which call for the application of the so-called non-medical security measures. ${ }^{2}$

Bearing in mind that the restraint to approach and communicate with the injured party belongs to non-medical security measures, it is necessary to specify the meaning of "conditions". Thus, "conditions" are understood as situations that stimulate the commission of criminal acts but are insufficient by themselves to cause the crime; instead, they have a criminogenic effect on "in concurrence with some personality characteristics" (Drakić,

331). Thus, the 2012 Act on amendments and changes to the $\mathrm{CC}$ removed this word from the name of the security measure, which was presented in the explanations for the Proposal of this Act as an issue of "editorial adjustments".

${ }^{2}$ Although not explicitly stated, this viewpoint is unequivocally advocated for by Lazarević (Lazarević, 2006: 252). 
2005: 20-21). It is certainly in accordance with the conception of security measures as a special type of criminal sanctions that should eliminate the causes of danger owing to which the offender may commit a criminal offense again in the future (Ćorović, 2015: 188). In terms of "conditions" as a feature for imposing relevant security measures (including the one envisaged in Article 89a CC), it is necessary to emphasize that such criminal sanction should restrain the offender "for a certain time to be in conditions that influence the future commission of crime" (Drakić, 2005: 21).

However, it should be noted that Article 89a paragraph 1 of the CC which regulates the legal grounds for the application of these criminal sanctions is rather vague as it uses a general formulation that the offender's "further commission of such criminal acts may be dangerous for the injured party". In fact, from the quoted part it is not clear how "danger to the injured party" is manifested. In some of the security measures (envisaged in Articles 81 - 84 and some measures in Article 87 of the CC) but certainly not all security measures (Art. 85-86, 88-89b), the legislator opted for danger (risk) in terms of "repeated danger of committing criminal acts in the future". Given that the security measures are, pursuant to the purpose of punishment specified in Article 78 of the $\mathrm{CC}$, aimed at eliminating criminal factors (conditions) that stimulate the commission of criminal offenses, in this situation "danger to the injured party" should be understood as a threat that the offender will repeat the criminal offense against the same injured party. Yet, as Article 89a par.1 CC states that restraint will be imposed "if it is deemed reasonable that further commission of the act may be dangerous for the victim", such a threat must be realistic and imminent; in effect, it should be interpreted as a higher degree of probability of repetition of the offense against the injured party. Namely, in certainly security measures, the legislator's intention has been guided by the specified quantity of probability or possibility of repeated criminal conduct (which is covered by the phrase "serious risk" in Art. 81-84 of the CC); therefore, the term "reasonable" (which is also used in the security measure under Article 85 of the CC) should be interpreted in that manner. ${ }^{3}$

This raises the following question: which conditions should be removed by applying the security measures envisaged in Article 89a of the CC? As the answer to this question is not expressly provided in Article 89a par. 1 of the $\mathrm{CC}$, the issue may possibly be addressed by understanding the relationship between the legal grounds for the application of this security measure and its content. Namely, the implementation of this security measure should prevent any contact between the offender and the injured party which may feature elements of disturbance and harassment, because that distressing contact creates a realistic and imminent risk to the injured party. Therefore, the offender's actions specified in Article 89a of the $\mathrm{CC}$ are prohibited because they represent acts (i.e. conditions of harassment) that are reasonably deemed to be dangerous to the injured party (victim), given the fact that the victim is exposed to risk of further violence or re-perpetration of the criminal act. Thus, it can be concluded that the restraint should preclude further abuse and victimization of the injured party.

However, we believe that one of the prescribed actions, formulated as a "further communication with the injured party", cannot per se have a harassing character. Namely,

\footnotetext{
${ }^{3}$ This raises the issue of the prognostic nature of security measures because it requires a quantification of risk, "which cannot be done in a criminal proceeding because there are no objective criteria for grading the risk; thus, it is clear that judges act intuitively or arbitrarily when deciding on the danger for the environment" (Drakić, 2007: 316) or, in this case, the danger for the injured party. Although controversial, this feature is inherent to all criminal sanctions that are designated as security measures.
} 
the concept of communication ${ }^{4}$ per se does not have a negative connotation; thus, an attempt to establish communication between the criminal offender and the injured party is not necessarily a bad thing. For this reason, it would be better to remove the term "communication" from the name of this security measure. More appropriately, the contents of this measure should be designated as "the restraint to approaching and further harassment of the injured party". When considering this issue, we shall not forget that communication ceases to exist if the offender (who may be driven by the best of intentions) repeats certain actions (e.g. trying to apologize to the victim) the despite the victims' disapproval or rejection. Then, communication turns into harassment. Consequently, the restraint shall not be considered violated if the offender calls the injured party on the phone in order to apologize or reconcile with the victim. However, if the offender keeps calling the victim in spite of being expressly told to stop any further contact, then a matter of communication turns into a harassment issue (Ćorović, 2015: 226, fn 845).

According to Article 89a paragraph 1 of the $\mathrm{CC}$, this security measure comprises a prohibition or restraint on: a) approaching the injured party at a specified distance; b) access to an area around the place of residence or workplace of the injured party; c) further harassment of the injured party; d) further communication with the injured party. The court may impose any of these restraints if it is deemed reasonable that the further commission of such actions (approaching, access, harassment and communication) may be dangerous for the injured party.

Given that this criminal sanction prohibits the offender to approach the injured party and access the victim's place of residence and/or workplace, its contents are expressed as a limitation of the offender's personal liberty, and specifically the freedom of movement. In our law, adequate restrictions on the freedom of movement are envisaged not as independent criminal sanctions but as certain obligations within a suspended sentence with supervision (Article 73 of the CC). The restriction of personal freedom imposed on the basis of this security measure does not seem to be much stricter than some limitations imposed in case of a suspended sentence with supervision. What distinguishes the former from the latter is the fact that the security measure defined in Article 89a of the CC is primarily aimed at protecting the security of the injured, which is not the case in the latter case. However, if so, the sentence of imprisonment would be the most effective measure to prevent unwanted contact or harassment of the injured party; thus, this traditional criminal sanction could be "declared" a security measure.

The analysis of comparative law demonstrates a highly controversial nature of this criminal sanction. In the Criminal Code of Spain, the restraining order is prescribed as a criminal sanction, prohibiting both access to and communication with the injured party, his/her relatives and other people (Article 33). In the Criminal Code of Croatia, the system of security measures includes the restraint to approach the injured party (Article 73 ) and the offender's removal from the shared place of residence or household (Article 74). The Criminal Code of Republika Srpska envisages similar security measures (in Art. 62a-62v). The Criminal Code of Slovenia does not prescribe this measure as a criminal sanction but rather as one of the obligations within a suspended sentence with supervision (Article 65 Section 3 Item 6) (Ćorović, 2015: 226). Considering the controversial nature of this criminal sanction/measure, domestic theorists posed the following question: whether it is justified to envisage this security measure as a special criminal sanction, and

\footnotetext{
${ }^{4}$ The term communication derives from the Latin word "communication", which means expression, exchange of information, sharing, conversation, contact, connection, discourse, thoroughfare (Vujaklija, 1992: 432).
} 
whether such prescription can ensure its effective implementation. There are also opinions that this measure should be regulated as one of the obligations within a suspended sentence with supervision (Stojanović, 2012: 331).

The concept of "the injured party", which is used in the name and contents of this security measure, should be understood within the meaning of Article 2 par. 1 item 11 of the Serbian Criminal Procedure Code (CPC), where the injured party is defined as "a person whose personal or property rights have been violated or threatened through criminal activity". This security measure may be imposed not only on the perpetrator of a criminal offence committed against the injured party but also on the accomplices, considering that Article 89a (1) of the Serbian CC uses the term "offender" which (according to the interpretative provisions in Article 112 par. 11 of the CC) includes both perpetrators and accomplices.

This security measure is supplementary in character, which means that it is never imposed alone but rather along with another criminal sanction. According to Article 80 par. 6 of the $\mathrm{CC}$, the restraint to approach and communicate with the injured party can be imposed in conjunction with a fine, community service, suspension of a driving license, a suspended sentence, or a judicial admonition.

The court determines the duration of these measures, which can range from six months to three years from the date of the final decision (Article 89a, par. 2 of the CC), whereby the time spent in prison or in a medical institution in charge of execution of the security measures is not included in the term of this measure (Article 89a, par. 3 of the CC). The latter provision is difficult to make sense of, given that the restraint to approach and communicate with the injured party may neither be imposed with a sentence of imprisonment nor imposed on a mentally incompetent person alongside with the security measure of compulsory psychiatric treatment and confinement in a medical institution (in terms of Article 80 par. 2 of the CC). This security measure can be terminated before the expiry of the specific period for which it was imposed if the legal grounds on which it was ordered cease to exist (Article 89a par. 4 of the CC). It should be noted that, since the introduction of this security measure in 2009 until the 2012 amendments, the Serbian CC did not prescribe the minimum term for this security measure.

The existing legislation pertaining to the restraint to approach and communicate with the injured party does not envisage the consequences affecting the offender in case of non-compliance with the imposed prohibitions. As already noted, this measure is imposed in conjunction with a fine, community service, suspension of a driving license, a suspended sentence or a judicial admonition, but the legislator does not prescribe what will happen to the offender in case of failure to comply with the prohibition imposed by this security measure. In addition, our positive law provisions do not contain rules on the execution of this measure. Namely, the Act on the Execution of Criminal Sanctions does not mention this measure in Chapter VI, which regulates the execution of these criminal sanctions. Article 19 of the Act on the Execution of Non-custodial Sanctions and Measures contains a provision on "control over the execution of the measure of restraining the offender from approaching, meeting or communicating with a certain party or other measures determined by court decision". However, the latter provision, however, refers to the restraint as a measure of procedural coercion aimed at prohibiting and restraining the offender from approaching, meeting or communicating with a certain party and visiting certain places, as prescribed in Articles 197 and 198 of the Serbian Criminal Procedure Code (CPC). Due to the above, this security measure is quite an ineffective tool in the process of counteracting and combating crime. 
Given that the rationale for this provision is the suppression of the crime of domestic violence, we may pose the question whether the violation of the restraint imposed on the basis of the security measure envisaged in Article 89a of the CC can be characterized as a special form of the crime of domestic violence prescribed in Article 194 par. 5 of the CC, where the act is defined as a violation of "a protection measure against domestic violence" imposed by a court according to the law. In theory, it is undisputed that this provision applies to violations of security measures that the (civil) court imposes on the basis of Art. 198 of the FA (Stojanović, 2012: 574; Dimovski, 2013: 141-142; Škulić, 2014: 43-44; Ćorović, Milić, 2016: 438). ${ }^{5}$ These questions can be topical because of the essential similarity of the security measure envisaged in Article $89 \mathrm{a}$ of the $\mathrm{CC}$ and the protection measures against domestic violence under the FA. Of course, this question makes sense only in situations where the security measure was imposed in criminal proceedings involving the crime of domestic violence, and not for any other crime. The question should be given a negative response because the restraint in Art. 89a of the $\mathrm{CC}$ is prescribed as a security measure, i.e. as a criminal sanction which must imply a direct consequence for the offender who has been imposed the sanction, in case he/she does not comply with the prohibitions and restrictions prescribed by the criminal sanction. It stems from the nature of criminal sanctions as repressive (forced) measures (Ćorović, 2010: 195-196).

For the same reason, we consider unacceptable the proposal that was presented in the 2015 Draft Act on changes and amendments to the CC, which provide for a new criminal offense, titled "Violation of the prohibition imposed by a security measure", which is defined as follows: "Whoever violates a prohibition specified by an imposed security measure shall be punished by a fine or imprisonment of up to six months". We also consider the proposal formulated in the Draft Act unacceptable, as wells as the interpretation that would allow for the violation of the restraint envisaged in Article 89a of the $\mathrm{CC}$ to be subsumed under the criminal offense prescribed in Article 194 par. 5 of the $\mathrm{CC}$, because they erase the differences between the effect of criminal judgments and security measures imposed thereof (as criminal sanctions) and the effect of the civil court judgments which impose civil measures provided under the FA. The standpoint that the violation of the restraint provided in Article 89a of the CC shall not be envisaged as a special form of domestic violence under Article 194 Section 5 of the CC is further supported as follows: although the rationale of the restraining measure envisaged in Article $89 \mathrm{a}$ of the $\mathrm{CC}$ is the suppression of criminal offence of domestic violence, this measure is not exclusively related to this criminal offence; thus, in case the criminal offender who committed an act of domestic violence were concurrently imposed the restraint envisaged in Article $89 \mathrm{a}$ of the $\mathrm{CC}$, he would be put in an unequal position in relation to the offender who committed some other offence which is punishable by the same security measure, in case of a violation of these restraints. Therefore, it would lead to the unequal treatment of citizens under the law. ${ }^{6}$

\footnotetext{
${ }^{5}$ In Article 32 par. 1, the Draft Act on Protection against Domestic Violence provides as follows: « A person who violates an emergency measure or a protection measure against domestic violence prescribed by the Family Act shall be punished by a term of imprisonment of up to 60 days». As already pointed out in legal theory, legalization of such a solution would lead to treating the same action (concurrently) as a criminal offense and a misdemeanor, which would cause practical problems in terms of the institute ne bis in idem (Voštinić, Lazović, 2016: 322).

${ }^{6} \mathrm{~A}$ similar argument may be found with other authors. Thus, in a study on domestic violence, on the occasion of the effect of violation of the restraint envisaged in Article 89a of the CC, the author states: "This measure is not reserved only for the protection of victims of domestic violence but also for victims of other actions, including those who will not be considered members of the family under the new legal provisions, but who will still need to be protected through this security measure" (Jovanović et all, 2012: 42).
} 


\section{DATA ON IMPOSING THE SECURITY MEASURE UNDER ARTICLE 89A OF THE CC}

In this part of the paper, we will explore some statistical data collected by the Republic Statistics Office and published in the bulletins of this institution on the annual basis. The data are related to the total number of recorded cases involving reporting, raising charges and convictions in criminal offences committed by adult offenders in the Republic of Serbia in the years 2011, 2012, 2013 and 2014. Before the year 2011, the RSO bulletins did not contain information on the security measure of restraint, which was introduced in September 2009. So, it can be assumed that the criminal sanction was not imposed in 2010, due to the effect of the principle nullum crimen, nulla poena sine lege and the fact that a certain period of time was needed for the criminal proceedings to be instituted on this matter. Data for the year 2015 were not available.

Before presenting and providing commentary on these data, it has to be noted that the bulletins of the Republic Statistics Office presented groups of criminal offenses rather than specific crimes for which this security measure was imposed. The bulletins provide data in absolute numbers about the total number of security measures imposed under Article 89a of the CC, including their specification in the observed period for each group of crimes and according to the offenders' gender. The data will be presented in Table 1.

Table 1 Groups of Crimes committed by Adult Offenders in the period 2011-2014

\begin{tabular}{|c|c|c|c|c|c|}
\hline & Year & 2011 & 2012 & 2013 & 2014 \\
\hline & Total & 1402 & 108 & 56 & 52 \\
\hline Gender & & 1241 & 101 & 54 & 51 \\
\hline structure & & 161 & 7 & 2 & 1 \\
\hline \multicolumn{6}{|l|}{ Groups of crimes } \\
\hline Against life and limb & & 93 & 10 & 2 & 3 \\
\hline Against the freedoms and rights of man and citizen & & 29 & 20 & 12 & 19 \\
\hline Against electoral rights & & 1 & - & - & - \\
\hline Against labor rights & & 5 & - & - & - \\
\hline Against honor and reputation & & 39 & 4 & - & - \\
\hline Against sexual freedom & & 4 & 4 & 1 & 1 \\
\hline Against marriage and family & & 149 & 19 & 25 & 26 \\
\hline Against intellectual property & & 4 & - & - & - \\
\hline Against property & & 344 & 18 & 9 & 1 \\
\hline Against the economy & & 48 & 1 & 1 & - \\
\hline Against the human health & & 34 & 2 & 1 & 1 \\
\hline Against the environment & & 21 & 1 & - & - \\
\hline Against general safety of people and property & & 10 & - & - & - \\
\hline Against public traffic safety & & 108 & 5 & 3 & - \\
\hline Against state authorities & & 59 & 2 & 2 & - \\
\hline Against justice & & 5 & 1 & - & - \\
\hline Against public order and peace & & 100 & 11 & - & 1 \\
\hline Against legal transactions & & 58 & 3 & - & - \\
\hline Against official duties & & 30 & 3 & - & - \\
\hline Against the army of Serbia & & 7 & - & - & - \\
\hline Crimes envisaged in special laws & & 254 & 4 & - & - \\
\hline
\end{tabular}

Source: Republic Statistics Office, Belgrade 
After the initial enthusiasm of domestic courts in imposing the security measure in 2011, when an impressive figure of 1402 imposed security measures of restraint to approach and communicate with the injured party was recorded, there was a drastic decline in the subsequent observation period. Moreover, there is an apparent downward trend in the number of imposed security measures over the observed years. Except for the year 2011, when we compare the absolute numerical data from 2012 and the data from 2013-2014, it may be concluded that the total number of the imposed security measures was reduced almost by half in 2013 and 2014. Some scholars also noted that in 2011, when the highest number of imposed security measures of restraint to approach and communicate with the injured party was recorded, the legal solution was incomplete in terms of the duration of this criminal sanction because the legislator did not prescribe the minimum of term for this security measure (Stojanović, 2013: 126).

The table also shows that the security measure under Article 89a of the CC was imposed for quite a heterogeneous group of crimes. Offenses against marriage and family, which include domestic violence, had prevalence only in the last two observed years, but not to a significant extent. In 2011, offenses against marriage and family were in the third place, as the security measure was more frequently imposed for the commission of crimes against property and crimes envisaged in special/secondary legislation. In 2012, offences against marriage and property were in the second place, after the crimes against freedoms and rights of man and citizen. Generally, it can be concluded that the latter category was the only stable category, where no substantial oscillations were recorded, considering that the security measure of restraint was equally imposed over the observed period. On the other hand, the most striking differences in terms of imposing this criminal sanction may be observed in the group of crimes against property, ranging from the staggering 344 cases in the year 2011 to only one case in 2014 .

It is difficult without detailed research, which requires a detailed analysis of case law, to give an adequate conclusion about what is the reason for this situation in terms of imposing the security measure restraining approach and communication with the injured party. However, it may be assumed that inadequate legislation and primarily the absence of execution procedure regulations, which should provide for the enforcement of court decisions, significantly discourage the judiciary to impose the security measure envisaged in Article Article 89a of the CC. For, what is the point of imposing this criminal sanction if it does not produce any effects in combating crime?

\section{FinAl CONSIDERATIONS AND SUGGESTION DE LEGE FERENDA}

It is clear from the provided discussion that the security measure of restraint to approach and communicate with the injured party, envisaged in Article Article 89a of the CC, does not contribute to the basic function of criminal law and the general purpose of criminal sanctions under Article 4 par. 2 of the CC, which is crime prevention and suppression of those criminal acts that violate or threaten the values protected by criminal legislation. Thus, as long as the legislator does not prescribe the specific consequences that will affect the offender for violating the restraint and as long as the enforcement issues are not explicitly regulated by the law, the judicial decisions where this security measure is imposed will remain "a dead letter of law". In this content, it is necessary to take concrete legislative steps to rectify the identified deficiencies. 
First and foremost, we believe that this restraint should not be envisaged as a security measure. We quite reasonably support the argument that such a restraint should be prescribed as an obligation accompanying a suspended sentence with supervision. It should be noted that such form of criminal justice has been affirmed in the Serbian system in recent years, through the adoption of the Act on the Execution of Non-custodial Sanctions and Measures. In Article 3, this Act envisages the so-called Probation Office, as an organizational unit responsible for alternative sanctions, which operates within the Directorate for the Execution of Criminal Sanctions.

In accordance with the above, we believe that the security measure under Article 89a of the $\mathrm{CC}$ should be removed. Instead, it should be envisaged as one of the obligations of protective supervision under Article 73 of the $\mathrm{CC}$, and designated as follows: $\underline{a}$ restraint/ban on approaching the injured party at a certain distance, accessing the place of residence or workplace, and prohibition of any harassment of the injured party. Considering that the enforcement of protective supervision is regulated by the Rules on the Execution of Non-Custodial Sanctions and Measures and the Operative Activities of the Probation Officer (Articles 14-28), which specifies the manner of executing each obligation envisaged in Article 73 of the $\mathrm{CC}$, the method of executing the proposed obligation concerning the ban on approaching and harassing the injured party could read: "In cooperation with the competent law-enforcement authority and through contact with the injured party, the probation officer shall check whether the convicted offender acts in compliance with the restraint on approaching the injured party at a certain distance, assessing the place of residence or workplace, and other forms of harassment of the injured party". The rules of procedure concerning the action to be taken by the probation officer in case of the offender's violation of protective supervision are already regulated in the Act on the Execution of Non-custodial Sanctions and Measures (Articles 34-37) as well as in the aforesaid Rules on the Execution of Non-Custodial Sanctions and Measures and the Operative Activities of the Probation Officer (Articles 14-28).

We believe that it would create a proper legal framework for the effective implementation of this restraint. The proposed solution may be challenged by the argument that the suspended sentence with protective supervision has not taken root and yielded considerable results in our legal system. However, there is a very clear step forward of the competent authorities to promote all forms of alternative reaction to crime, which certainly includes the aforementioned modality of suspended sentence. The positive development is reflected not only through the adoption of new regulations but also through opening the offices for alternative sanctions all over the Republic of Serbia in the past few years. ${ }^{7}$

\footnotetext{
${ }^{7}$ The best evidence of these developments are the annual reports of the Directorate for the Execution of Criminal sanctions, which are available at the official website of this state authority. Unfortunately, the last available report was made for the year 2013. Considering that the legislation governing the enforcement of non-custodial sanctions and measures was adopted in 2014 and 2015, we still have no data on how the new legal solutions (including those pertaining to the suspended sentence with protective supervision) have been implemented in practice.
} 


\section{REFERENCES}

Bilten - Punoletni učinioci krivičnih dela u Republici Srbiji 2011. - Prijave, optuženja i osude (Bulletin - Adult offenders of criminal offenses in the Republic of Serbia 2011 - Charges, prosecutions and convictions), Beograd: Republički zavod za statistiku, pristup 30.10.2016, http://webrzs.stat.gov.rs/WebSite/repository/documents/ 00/00/89/64/SB_558_Punoletni_ucinioci_kd.pdf,

Bilten - Punoletni učinioci krivičnih dela u Republici Srbiji 2012. - Prijave, optuženja i osude (Bulletin - Adult offenders of criminal offenses in the Republic of Serbia 2012 - Charges, prosecutions and convictions). Beograd: Republički zavod za statistiku, pristup 30.10.2016. http://webrzs.stat.gov.rs/WebSite/repository/ documents/00/01/24/91/SB_576_Punoletni_uciniociKD2012.pdf

Bilten - Punoletni učinioci krivičnih dela u Republici Srbiji 2013. - Prijave, optuženja i osude (Bulletin - Adult offenders of criminal offenses in the Republic of Serbia 2013 - Charges, prosecutions and convictions) Beograd: Republički zavod za statistiku, pristup 30.10.2016. http://webrzs.stat.gov.rs/WebSite/repository/documents/00/01/62/77/SB-588-PunoletniUciniociKD.pdf,

Bilten - Punoletni učinioci krivičnih dela u Republici Srbiji 2014. - Prijave, optuženja i osude (Bulletin - Adult offenders of criminal offenses in the Republic of Serbia 2014 - Charges, prosecutions and convictions) Beograd: Republički zavod za statistiku, pristup 30.10.2016. http://webrzs.stat.gov.rs/WebSite/repository/ documents/00/01/97/00/SB_603_Pnoletni_ucinioci_KD_2014.pdf,

Ćorović, Emir (2010). Kritički osvrt na progresiju mera bezbednosti u krivično zakonodavstvo Republike Srbije (Critical review of the progression of security measures in the criminal legislation of the Republic of Serbia). In: Petar Stanojević (ed.), Zbornik radova: Aktuelna pitanja materijalnog, procesnog i izvršnog krivičnog prava u nacionalnim krivičnim zakonodavstvima i međunarodnom krivičnom pravu, Kosovska Mitrovica: Pravni fakultet u Univerziteta u Prištini sa privremenim sedištem u Kosovskoj Mitrovici, pp. 179-198.

Ćorović, Emir (2015). Sistem krivičnih sankcija Republike Srbije. (System of Criminal Sanctions in the Republic of Serbia) Novi Pazar - Niš: SVEN.

Ćorović Emir, Milić Ivan (2016). Zaštita od nasilja u porodici u zakonodavstvu Republike Srbije - sa posebnim osvrtom na krivičnopravnu legislativu (Protection against domestic violence in the legislation of the Republic of Serbia - with special reference to criminal legislation). In: Anton Kasipović, Stanko Bejatović, Stanko Stanić, Miodrag Simović, Ljubinko Mitrović, Pero Dunjić (ed.), Zbornik radova: Krivičnopravni instrumenti suprostavljanja terorizmu i drugim krivičnim djelima nasilničkog karaktera, Banja Luka - Teslić: Internacionalna asocijacija kriminalista - Ministarstvo pravde Republike Srpske - Srpsko udruženje za krivičnopravnu teoriju i praksu, pp. 419-451.

Dimovski, Darko (2013). Krivičnopravna zaštita žena (Protection of Women in Criminal Law). In: Slobodanka Konstantinović Vilić (ed.), Zbornik radova: Pravna krinika za zaštitu prava žena - norme i praksa. Beograd - Niš: Autonomni ženski centar - Ženski istraživački centar za edukaciju i komunikaciju, pp. 131-147.

Drakić, Dragiša (2005). Mere bezbednosti psihijatrijskog karaktera u krivičnom pravu Srbije (Security Measures of psychiatric character in Serbian criminal law). Prosveta: Novi Sad.

Drakić Dragiša (2007). Društvena opasnost učinioca i krivično pravo. ('Social danger' of a offender and criminal law), Zbornik radova Pravnog fakulteta u Novom Sadu, No. 3, pp. 307-324.

Godišnji izveštaj o radu Uprave za izvršenje krivičnih sankcija za 2013. godinu (Annual Report of the Administration for Enforcement of Criminal Sanctions 2013). Beograd: Ministarstvo pravde Republike Srbije - Uprava za izvršenje krivičnih sankcija, http://www.uiks.mpravde.gov.rs/images/Godisnji_izvestaj_UIKS-a_za_2013.pdf, pristup 30.10.2016

Jovanović, Slađana; Simeunović-Patić, Biljana; Macanović, Vanja (2012). Krivičnopravni odgovor na nasilje u porodici $u$ Vojvodini (Criminal law response to domestic violence in Vojvodina). Novi Sad: Pokrajinski sekretarijat za rad, zapošljavanje i ravnopravnost polova.

Lazarević, Ljubiša (2006). Komentar Krivičnog zakonika Republike Srbije (Commentary of the Criminal Code of the Republic of Serbia). Beograd: Savremena administracija

Srzentić Nikola, Stajić Aleksandar, Lazarević Ljubiša (1979). Krivično pravo SFRJ: Opšti deo (Criminal Law of SFRY). Beograd: Savremena administracija.

Stojanović, Zoran (2013). Komentar Krivičnog zakonika (Commentary of the Criminal Code). Beograd: Službeni glasnik.

Stojanović, Zoran (2013). Da li je Srbiji potrebna reforma krivičnog zakonodavstva? (Does Serbia Need a Criminal Legislation Reform?), Crimen - Časopis za krivične nauke, No. 2, pp. 119-143.

Škulić, Milan (2014). Nasilje u porodici: problem zakonske inkriminacije i sudske prakse (Domestic Violence: problem of legal incrimination and judicial practice). In: Dragana Kolarić (ed.), Nasilje u Srbiji: uzroci, oblici, posledice i društvene reakcije. Tom I. Beograd: Kriminalističko-policijska akademija-Hans Seidel, str. 34-50. 
Voštinić, Mirko; Lazović, Marija (2016). Kratka analiza Prednacrta zakona o zaštiti od nasilja u porodici (A brief analysis of the first draft law on protection against domestic violence). In: Stanko Bejatović (ed.), Evropske integracije i kazneno zakonodavstvo (poglavlje 23 - norma, praksa i mere harmonizacije). Beograd: Srpsko udruženje za krivičnopravnu teoriju i praksu, str. 314-324.

Vujaklija, Milan (2012). Leksikon stranih reči i izraza (Lexicon of Foreign Words and Phrases). Beograd: Prosveta.

Vuković, Igor (2015). Prekršajno pravo (Misdemeanor Law). Beograd: Pravni fakultet Univerziteta u Beogradu.

\section{Legislation}

Krivični zakonik (Criminal Code; CC), Službeni glasnik RS, 85/2005; 88/2005; 107/2005; 72/2009; 111/2009; 121/2012; 104/2013; 108/2014

Porodični zakon (Family Act), Službeni glasnik RS, 18/2005; 72/2011; 6/2015.

Pravilnik o izvršenju vanzavodskih sankcija i mera i organizaciji i radu Poverenika (Rules on the Execution of Non-custodial Sanctions and Measures, and on the Organization and Activities of Probation Officers), Službeni glasnik RS, 30/2015

Predlog zakona o izmenama i dopunama Krivičnog zakonika iz 2012. (The 2012 Draft Act on amendments and supplements to the Criminal Code), pristup: 25.10 .2016

http://www.parlament.gov.rs/upload/archive/files/lat/pdf/predlozi_zakona/941-13Lat.pdf

Zakon o izvršenju krivičnih sankcija (Act on the Execution of Criminal Sanctions), Službeni glasnik RS, 55/2014.

Zakon o izvršenju vanzavodskih sankcija i mera (Act on the Execution of Non-custodial Sanctions and Measures), Službeni glasnik RS, 55/2014.

Zakonik o krivičnom postupku (Criminal Procedure Code; CPC), Službeni glasnik RS, 72/2011; 101/2011; $121 / 2012 ; 32 / 2013 ; 45 / 2013 ; 55 / 2014$

\section{KRITIČKI OSVRT NA MERU BEZBEDNOSTI ZABRANE PRIBLIŽAVANJA I KOMUNIKACIJE SA OŠTEĆENIM IZ ČLANA 89a KRIVIČNOG ZAKONIKA SRBIJE}

Autori u radu analiziraju meru bezbednosti zabrane približavanja i komunikacije sa oštećenim iz člana 89a Krivičnog zakonika Srbije, koja je uvedena njegovim izmenama i dopunama iz 2009. godine. Iako ova krivična sankcija u domaćem krivičnom pravu postoji već sedam godina, postoje ozbiljni legislativni nedostaci koji se vezuju za njenu regulative. Naime, pozitivno krivično pravo Republike Srbije uopšte ne sadrži govori o tome kakve posledice nastupaju po osuđenog ukoliko prekrši ovu zabranu, niti predviđa pravila za izvršenje ove mere bezbednosti. Otuda se mogu javiti ozbiljni problem u izricanju $i$ primeni predmetne krivične sankcije, a iz odgovarajućih podataka je vidljivo da je sudovi iz godine $u$ godinu izriču sve manje izriču. Otuda su autori dali određene predloge de lege ferenda, odnosno da se postojeća zabrana ukloni iz sistema mera bezbednosti i da se predvidi kao jedna od obaveza kod uslovne osude sa zaštitnim nadzorom.

Ključne reči: zabrana približavanja i komunikacije sa oštećenim, mera bezbednosti, uslovna osuda sa zaštitnim nadzorom 